
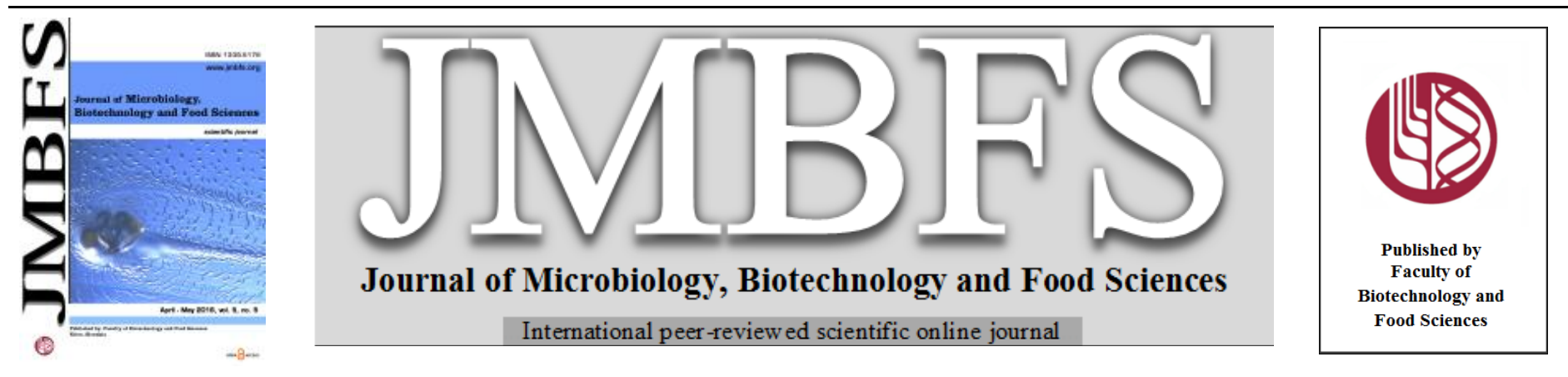

\title{
CONTROLLING MICROBIAL GROWTH IN INNOVATIVE DIETARY SUPPLEMENT BASED ON THE BIOMASS OF YEAST YARROWIA LIPOLYTICA
}

\author{
Wojciech Białas*, Adrian Czerniak, Anna Dobrowolska, Joanna Wojciechowska, Włodzimierz Grajek
}

Address(es): Wojciech Białas,

Poznan University of Life Sciences, Department of Biotechnology and Food Microbiology, Wojska Polskiego 48, 60-637 Poznań, Poland, +48618466025.

*Corresponding author: wbialas@up.poznan.pl

doi: $10.15414 / j m b f s .2016 .5 .5 .389-395$

ARTICLE INFO

Received 18. 5. 2015

Revised 11. 11. 2015

Accepted 15. 1. 2016

Published 1. 4. 2016

Regular article

open $\partial$ access

\begin{abstract}
The growing demand for meat and dairy products necessitates the intensification of the production of feeds containing high-protein components. Yarrowia lipolytica biomass constitutes a rich source of easily digestible proteins and numerous vitamins, which makes it a valuable additive for both liquid and dry feeds. Unfortunately, the liquid products are susceptible to the growth of undesirable microflora. The aim of the presented research was to assess the possibility of using selected chemical substances to stabilize the highprotein liquid products acquired from Yarrowia lipolytica biomass. The research was designed with the use of a statistical method based on mixture designs. Microbiological stability was assessed using the results of culture tests aimed at calculating the total number of mesophilic bacteria, yeasts, molds, and bacteria from the coli and Salmonella sp. groups. Storage tests were performed at temperatures of 4 and $25^{\circ} \mathrm{C}$. Sodium benzoate, potassium sorbate and phosphoric acid were used as preservatives.

The use of preservatives resulted in a significant decrease in the numbers of bacteria during storage. After 30 days of storage, the total number of bacterial cells was $0.95 \pm 0.11$ and $1.5 \pm 0.09 \log _{10} \mathrm{Cfu} \mathrm{ml}^{-1}$, respectively, for storage tests at temperatures of 4 and $25^{\circ} \mathrm{C}$. A product with optimum preservative mixture composition, stored at $4^{\circ} \mathrm{C}$, should contain $1297 \mathrm{mg}^{-1}$ of sodium benzoate and $1203 \mathrm{mg} \mathrm{l}^{-1}$ of phosphoric acid. In the case of products stored at $25^{\circ} \mathrm{C}$, the concentration of sodium benzoate and phosphoric acid should be $1307 \mathrm{mg}$ $\mathrm{l}^{-1}$ and $1197 \mathrm{mg} \mathrm{l}^{-1}$, respectively.
\end{abstract}

Keywords: Yarrowia lipolytica, cavitation, liquid feed, microbial stability, preservatives

\section{INTRODUCTION}

Livestock production has recently seen dynamic growth, which is highly correlated with the increasing wealth of societies in developing countries. The growing demand for meat and dairy products necessitates the intensification of the production of feeds containing high-protein components. The demand for easily assimilated protein is very high, since the production of $1 \mathrm{~kg}$ of meat requires $3-10 \mathrm{~kg}$ of grain (Tilman et al., 2002). Current livestock production is mainly based on the use of feeds containing soybean meal and fish meal Soybean meal, due to its high amount of easily digestible protein and relatively low fat content, is an excellent source of protein for poultry, piglets, and calves (Bertheau and Davison, 2011). By-products of the biofuel industry, such as dried distiller's grains with solubles (DDGS) created during the production of bioethanol from starch-based substrates, may also constitute a source of protein and energy. Unfortunately, the variability of this product is a significant drawback. It results from the variability of the raw materials used (e.g. corn) as well as of the conditions in which the processes of fermentation and distillation take place (Cozannet et al., 2010). Yeast biomass, which contains about $40 \%$ protein, may be used as an alternative to soybean meal and DDGS. According to the newest research, feed supplementation with inactive dry yeast (Saccharomyces cerevisiae) acquired after alcoholic fermentation does not have any negative effect on feed use by animals and provides comparable carcass gain (Campos et al., 2014). The yeast Yarrowia lipolytica is also gaining increasingly wider interest on the part of the feed industry. In 2009, a Polish company, Skotan $\mathrm{SA}$, in cooperation with scientists from the Wrocław University of Environmental and Life Sciences, designed a worldwide unique technology for the industrial production of Yarrowia lipolytica feed yeast biomass (Rymowicz, 2009). This strain is capable of intensive growth on vegetable fats, degumming, and glycerin fraction created during biodiesel production. Yarrowia lipolytica biomass constitutes a rich source of easily digestible proteins $(41-45 \%)$ and numerous vitamins, which makes it a valuable feed additive (Baszczok and Rymowicz, 2011). As a result of these investigations, the European Feed Manufacturers' Federation (FEFAC) decided to authorize the sale of $Y$. lipolytica feed yeast produced from crude glycerol in 2010. The powdered form of the product, acquired through spray drying, was registered under catalog number 00
575-EN (Rywińska et al., 2013). Unfortunately, within the last several years the price of technical glycerol, which is the main raw material in the process of producing the above-mentioned yeast, rose significantly. In 2010, it was about 90 euros/ton, while currently it is 275 euros/ton. As a result, the technology developed in 2009 was largely modified. The energy-intensive drying process was abandoned, and the powdered product was replaced with a liquid version. An innovative method is used to inactivate the yeast cells. It is based on hydrodynamic cavitation and enables effective cell disintegration. The resulting suspension, rich in easily assimilated protein, constitutes an excellent basis for the preparation of liquid animal feed. Feeding systems based on liquid feeds have numerous advantages and, therefore, are gaining popularity among breeders. The use of liquid feeds provides more flexibility and, consequently, ensures better control and modification capabilities for feeding systems. This improves the utilization of nutrients, gut health, and animal well-being, which, in turn, reduces the use of pharmaceuticals (Plumed-Ferrer and Von Wright, 2009).

Unfortunately, the product obtained through hydrodynamic cavitation is characterized by high susceptibility to microbiological infections due to its high content of easily assimilated nutrients. It retains its stability in cold room conditions for several days only. From a practical standpoint, this makes transportation significantly more difficult and forces end recipients to implement costly modernizations to the storehouses in the vicinity of their barns or piggeries. Hence, the goal of the presented study was to establish the optimum dose of preservatives enabling the storage of the liquid preparation for at least 30 days at a temperature of $25^{\circ} \mathrm{C}$. The preservatives which were used, i.e. sodium benzoate, potassium sorbate, and phosphoric acid, are chemical substances commonly utilized in the food industry for stabilizing different types of products (Aderinola and Oluwamukomi, 2014; Lennerz et al., 2015). They are characterized by a very wide spectrum of antibacterial effects, high activity in relatively low concentrations, and thermal stability in low $\mathrm{pH}$ environments. Moreover, these substances have no influence on the color and taste of the finished product (Alnoman $\boldsymbol{e t}$ al., 2015). The research was designed with the use of a statistical method based on mixture designs. Microbiological stability was assessed on the basis of culture tests. 


\section{MATERIAL AND METHODS}

\section{Microorganism}

The strain used in this study was Yarrowia lipolytica YL-A101, which belongs to the Department of Biotechnology and Food Microbiology at Wroclaw University of Environmental and Life Sciences, Poland. The strain was maintained on YPG slants stored at $5{ }^{\circ} \mathrm{C}$. For long time storage the strain was preserved in a laboratory culture collection as a glycerol stocks stored at $-80^{\circ} \mathrm{C}$.

\section{Medium composition}

Biomass production was conducted on the use of the production medium described in patent US 2011/0111090 A1 (Baszczok and Rymowicz, 2011) crude glycerol (methanol-free by-product from biodiesel production, LOTOS Group, Czechowice-Dziedzice, Poland) - $50 \mathrm{~g} \mathrm{l}^{-1}$; $\left(\mathrm{NH}_{4}\right)_{2} \mathrm{SO}_{4}-12.6 \mathrm{~g} \mathrm{l}^{-1}$; urea $4.0 \mathrm{~g} \mathrm{l}^{-1} ; \mathrm{MgSO}_{4} \times 7 \mathrm{H}_{2} \mathrm{O}-1.0 \mathrm{~g} \mathrm{l}^{-1} ; \mathrm{KH}_{2} \mathrm{PO}_{4}-0.5 \mathrm{~g} \mathrm{l}^{-1}$; yeast extract $-0.5 \mathrm{~g} \mathrm{l}^{-1}$. All chemicals were purchased from POCh (Poland).

\section{Production of liquid diet supplements}

The inoculum development for large scale cultivation process was described on Fig. 1. The pre-inoculum was produced from the YPG slants stored at $5{ }^{\circ} \mathrm{C}$, and microbial cells were transferred to conical flask with a $250 \mathrm{ml}$ capacity containing $50 \mathrm{ml}$ of growth medium. The growth medium for pre-inoculum preparation included the following composition in $\mathrm{g}$ 1-1: glycerol: 40; yeas extract: 20; bacto peptone: 30 . The flask was maintained in a shaker at $200 \mathrm{rpm}$ and $30 \pm 1{ }^{\circ} \mathrm{C}$ for $48 \mathrm{~h}$. After $48 \mathrm{~h}$ of cultivation, culture was used to inoculate the first seed fermentor containing $0,01 \mathrm{~m}^{3}$ of production medium. The $0,02 \mathrm{~m}^{3}, 0,2 \mathrm{~m}^{3}$ and $2 \mathrm{~m}^{3}$ fermentors containing $0,01 \mathrm{~m}^{3}, 0,1 \mathrm{~m}^{3}$ and $1 \mathrm{~m}^{3}$ of production medium were used for the first, second and third-stage liquid seed culture, respectively. All cultures were performed batch-wise in aerobic conditions. The last stage of liquid supplement production was the cultivation of the Yarrowia lipolytica YLA101 strain in an industrial scale bioreactor with total capacity of $15 \mathrm{~m}^{3}$ and working volume of $12 \mathrm{~m}^{3}$. The culture was maintained at $30 \pm 1^{\circ} \mathrm{C}$ and the $\mathrm{pH}$ was adjusted automatically to 3.5 with $10 \mathrm{M}$ sodium hydroxide solution. The dissolved oxygen level was automatically controlled by adjusting the agitation within the range of $120-400 \mathrm{rpm}$ to maintain over $20 \%$ of saturated dissolved oxygen (at a constant aeration rate of $1.5 \mathrm{vvm}$ ). Foam formation was controlled by automatic addition of Acepol 83E (Emerald Foam Control, Germany). Biomass productivity in the above-mentioned conditions was about $2.5 \mathrm{~g}^{-1} \mathrm{~h}^{-1}$, while final cell concentration in post-culture liquid was $33 \mathrm{~g}$ dry weight $1^{-1}$. After the cultivation process, the cell suspension was pumped into a storage tank.

The goal of the next stage was the disintegration of cell biomass leading to cell death and the release of cell contents into the post-culture liquid. This process was conducted with the use of a hydrodynamic continuous cavitation device (Unister Plus, Poland). The cavitation device was equipped with a high-pressure piston pump and a cavitation head. The maximum operating pressure achieved during cavitation was $10 \mathrm{MPa}$. The yield of the device under the said pressure was $3.5 \mathrm{~m}^{3} \mathrm{~h}^{-1}$. Hovewer, the cell biomass disintegration was conducted at a pressure of $8.2 \mathrm{MPa}$; the number of suspension passages through the cavitation head was 18; the temperature during cavitation was $72 \pm 2{ }^{\circ} \mathrm{C}$. A microprocessor controller equipped with a resistance temperature sensor (Pt-100, Apar, Poland) coupled with an actuator in the form of an electromagnetic valve assembly (Danfoss, Denmark) and a shell and tube heat exchanger with straight corrugated tubes (Secespol, Poland) was used to maintain constant temperature. After the cavitation process, the suspension was cooled down on a heat exchanger to a temperature of $10{ }^{\circ} \mathrm{C}$ and pumped into a storage tank feeding a distribution line for $2 \mathrm{~L}$ polyethylene bags, which were equipped with secure stoppers and silicone rubber membranes. The storage tanks and the distribution line were not aseptic. The product was then used for further research aimed at establishing the optimum composition of the preservative mixture.

\section{Experimental design}

A characteristic feature of experimental design for mixtures is the condition of factor summability and linear restrictions on the values of these factors. In practice, this means that in a given experimental variant individual factor levels are fractions whose sum always equals 1 (Cox and Reid, 2000). Three-factor Doptimal design, involving the performance of 20 experiments, was used to establish the influence of individual preservatives on the microbiological stability of the product (Table 1). The minimum and maximum factor levels used in the research were the following: sodium benzoate, SB $\left(0-2500 \mathrm{mg} \mathrm{l}^{-1}\right)$, sodium sorbate, SS $\left(0-2500 \mathrm{mg} \mathrm{l}^{-1}\right)$ and $75 \%$ (w/w) phosphoric acid, PA $(0-2500 \mathrm{mg} 1$ $\left.{ }^{1}\right)$. The order in which the experiments were performed was randomized, which fulfils the requirement for independent and random distribution of observations. Such practice helps avoid the influence of unknown nuisance variables. All preservatives were purchased from Sigma-Aldrich (Germany).

\section{Product preparation with the addition of preservatives}

The preservatives in a given mixture (Tab. 1) were dissolved in distilled water and filtered using a filter with pore diameter of $0.22 \mu \mathrm{m}$ (Millipore, USA). In order to reduce the risk of recurrence of microbiological infection, the preservatives were added to the product in aseptic conditions. The outside of the bags was cleansed with a $75 \%(\mathrm{v} / \mathrm{v})$ ethanol solution. Then the bags were placed in a laminar flow cabinet (Holten, Denmark). The preservative solutions were introduced through a membrane (previously washed with a $75 \%(\mathrm{v} / \mathrm{v})$ ethanol solution) with the use of a sterile $50 \mathrm{ml}$ syringe with a sterile needle. After mixing, the bags were moved to climate chambers with temperatures of 4 or $25^{\circ} \mathrm{C}$, depending on the variant of the experiment (Philips, Netherlands). The bags were stored (protected from light) for 30 days. After that time, the bags were once again placed in a laminar flow cabinet; $200 \mathrm{ml}$ samples were collected for microbiological analyses. Each experiment was repeated three times. Bags containing the product without any preservatives added were used as control samples.

\section{Microbiological analysis}

The samples for microbiological analyses were prepared in accordance with the Polish standards concerning the microbiological examination of food and animal feeds (PN-EN ISO 6887-1:2000; PN-EN ISO 7218:2008). Total aerobic mesophilic bacteria count was calculated in Plate Count Agar (PCA) (Biocorp Poland) and incubated at $30{ }^{\circ} \mathrm{C}$ for $72 \mathrm{~h}$ (PN-EN ISO 4833-2:2013-12). Total yeast and mold count was calculated in modified Dichloran Rose Bengal Chloramphenicol agar (DRBC) (Biocorp, Poland) and incubated at $25{ }^{\circ} \mathrm{C}$ for 5 days (PN-ISO 21527-1:2009). The presence of Escherichia coli was determined using Lauryl Sulfate Broth (LSB) (Biocorp, Poland) after incubation at $37^{\circ} \mathrm{C}$ for 24h (PN-ISO 4831:1998). The presence of Salmonella spp. was established with the use of Xylose Lysine Deoxycholate Agar (XLDA) (Biocorp, Poland) after incubation at $37^{\circ} \mathrm{C}$ for $24 \mathrm{~h}$ (PN-EN ISO 6579:2003). Microbiological data was expressed as a logarithm of colony forming units per $\mathrm{ml}\left(\log _{10} \mathrm{Cfu} \mathrm{ml}^{-1}\right)$.

\section{Data analysis and process optimization}

The data from the microbiological assays was used to calculate the coefficients of the Scheffé quadratic equation:

$$
Y=\sum_{i=1}^{q} \beta_{i} x_{i}+\sum_{i<j}^{q-1} \sum_{j}^{q} \beta_{i j} x_{i} x_{j}
$$

Where $\mathrm{Y}$ is the dependent variable and $\beta$ is the regression coefficient for each component. This model contains $q$ linear terms $\left(\beta_{i} x_{i}, i=1,2 \ldots, q\right)$ and $Q=q(q-$ 1)/2 quadratic cross product terms $\left(\beta_{i j} x_{i} x_{j}, 1 \leq i<j \leq q\right)$. Statistical tests were performed at a significance level of $\alpha=0.05$. The accuracy and general ability of the above mathematical model were evaluated using the adjusted coefficient of determination Adj- $\mathrm{R}^{2}$ and model $p$ value. A regression model was used to establish the optimum composition of the preservative mixture, enabling efficient reduction of the growth of foreign microflora in the product during storage. In order to verify the pertinence of the mathematical model and the developed optimum conditions, two confirmation experiments were run on the product with the addition of preservatives. Using the point prediction capability of the software, the number of viable bacterial cells after the storage period was predicted, together with the $95 \%$ prediction intervals, and compared with the observed values. The Design-Expert 9 (Stat-Ease, USA) and Origin 9.1 Pro (OriginLab, USA) commercial software was used for the regression and graphical analyses of the obtained data.

\section{RESULTS}

\section{Microbiological quality assessment of the control sample}

The production technology of the diet supplement based on the yeast Yarrowia lipolytica consists of several stages (Fig.1). Analysis of the production system revealed two critical control points which may constitute a potential source of secondary microbiological contamination on the production line. The first point was the hydrodynamic cavitation system, the purpose of which is the disintegration of yeast cells. The potential operation of this device with nonoptimal parameters (lower temperature, cavitation pressure or lower number of passages) may reduce the efficiency of the process. As a result, the living microbial cells present in the product were capable of further growth during storage. The storage tanks and the distribution line, which was not aseptic, constituted another critical point. Taking into consideration the two control points, the assessment of the microbiological quality of the product was performed directly after hydrodynamic cavitation and distribution to polyethylene bags. 

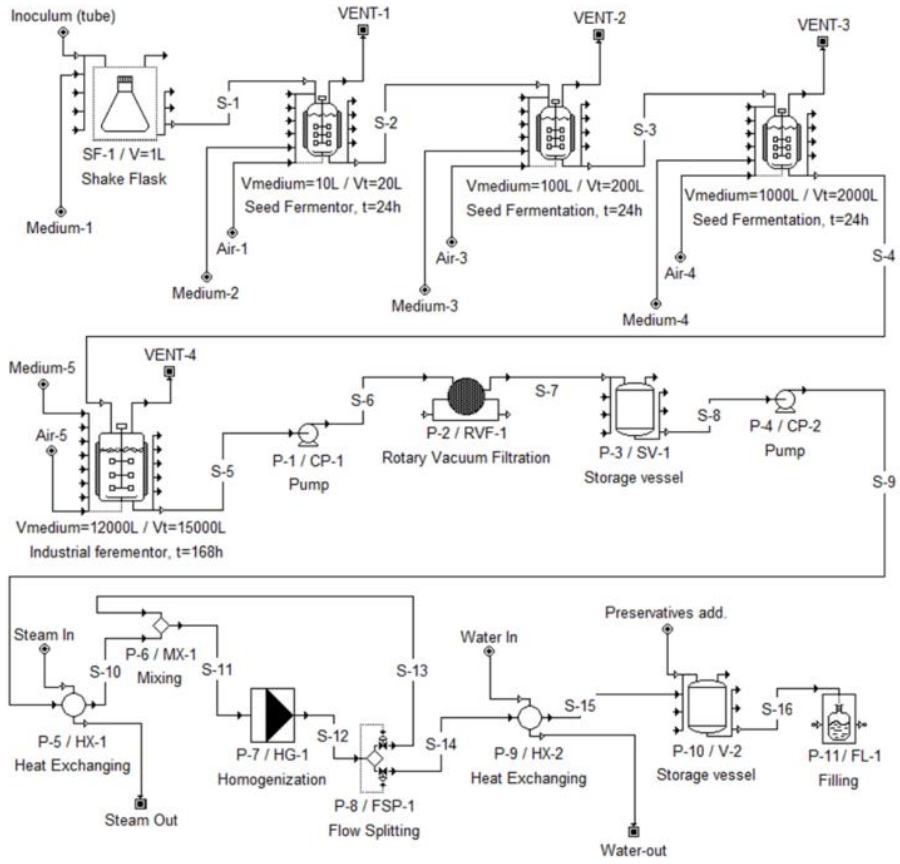

Figure 1 Processing line for the production of the diet supplement based on the yeast Yarrowia lipolytica. S-1...S-16 - stream numbers; P-1...P-11 - procedure numbers

In the first sample, collected directly after the head of the cavitation device, none of the studied groups of microorganisms were found. Therefore, both yeast cells and any potential foreign microflora was inactivated during disintegration. The second sample, constituting the finished product after distribution to polyethylene bags, contained no yeasts, molds, or bacteria from the coli and Salmonella sp. groups. However, the large number of aerobic mesophilic microorganisms was of concern, as it amounted to $2.01 \pm 0.04 \log _{10} \mathrm{Cfu} \mathrm{ml}^{-1}$. This number was growing during storage and after 30 days it amounted to $3.52 \pm 0.28$ and $6.21 \pm 0.15 \log _{10}$ $\mathrm{Cfu} \mathrm{ml} \mathrm{m}^{-1}$, respectively, for samples stored at temperatures of 4 and $25^{\circ} \mathrm{C}$. In

accordance with the national standards concerning the microbiological quality of food and animal feeds, the maximum total number of aerobic mesophilic bacteria should not exceed $3 \times 10^{6} \mathrm{Cfu} \mathrm{g}^{-1}\left(6.47 \log _{10} \mathrm{Cfu} \mathrm{g}^{-1}\right)$ (PN-EN ISO 7218:2008) Therefore, the product stored for a period of 30 days in cold room conditions met these quality criteria. The results for samples stored at room temperature provided significantly worse results. After 30 days, the number of cells was slightly lower than the upper limit set by the above-mentioned national standard It needs to be pointed out that the European Union currently has no explicit criteria concerning the maximum acceptable limits for microbiological contamination in animal feeds (Kwiatek et al., 2008). According to the currently applied criteria, only the presence of Salmonella in $25 \mathrm{~g}$ of feed and $C$. perfringens in $1 \mathrm{~g}$ of animal meal is considered unacceptable. The acceptable number of bacteria from the Enterobacteriaceae family in animal meals has also been reduced (it is assumed that in 2 out of 5 analyzed samples, the level of contamination with these bacteria cannot exceed $300 \mathrm{Cfu} \mathrm{g}^{-1}$ ). Taking this into consideration, the product could theoretically be put on the market in its original form (without any addition of preservatives), provided that the rules concerning the so-called continuity of the cold chain are observed. Otherwise, the intensive growth of foreign microflora will cause a gradual decrease of the nutrient content released from yeast cells during disintegration. The fulfillment of this condition is usually quite difficult and is associated with additional investment costs, both on the part of the distributor and end recipient. In order to eliminate the necessity of using lowered temperatures during transportation and storage of the finished product, a decision was made to use preservatives.

\section{The influence of preservatives on product stability}

As indicated by the data presented in Tab. 1, the number of bacteria, expressed as $\log _{10} \mathrm{Cfu} \mathrm{ml}^{-1}$, differed significantly depending on the composition of the preservative mixture. In the case of samples stored in cold room conditions, depending on the variant of the experiment, the number of cells varied from 1.0 to $3.62 \log _{10} \mathrm{Cfu} \mathrm{ml} \mathrm{m}^{-1}$. Storage at $25^{\circ} \mathrm{C}$ resulted in slightly higher infection levels, with the number of cells ranging from 1.0 to $3.72 \log _{10} \mathrm{Cfu} \mathrm{ml} \mathrm{m}^{-1}$. Therefore, in the case of samples containing preservatives, storage temperatures were not a very significant factor. However, the applied additives enabled a reduction of the number of cells by several orders of magnitude in comparison to the control sample. In order to establish how the composition of the preservative mixture influenced the change of the number of bacterial cells during storage, the collected data was analyzed with the use of backward stepwise regression.

Table 1 Component concentrations in the preservative mixtures prepared in accordance with mixture designs and experiment results expressed as Log ${ }_{10} \mathrm{Cfuml}^{-1}$ from the total number of mesophilic bacteria (TMB).

\begin{tabular}{|c|c|c|c|c|c|c|c|c|}
\hline \multirow[b]{2}{*}{ Run } & \multicolumn{3}{|c|}{ Components in actual scale } & \multicolumn{3}{|c|}{ Components in real scale* } & \multicolumn{2}{|c|}{ Dependent variables } \\
\hline & $\begin{array}{c}\text { Sodium } \\
\text { benzoate } \\
{\left[\mathrm{mg} \mathrm{l}^{-1}\right]} \\
\end{array}$ & $\begin{array}{l}\text { Sodium } \\
\text { sorbate } \\
{\left[\mathrm{mg} \mathrm{l}^{-1}\right]} \\
\end{array}$ & $\begin{array}{c}\text { Phosphoric } \\
\text { acid } \\
{\left[\mathrm{mg} \mathrm{l}^{-1}\right]} \\
\end{array}$ & $\begin{array}{c}\text { Sodium } \\
\text { benzoate } \\
\mathrm{X}_{1} \\
\end{array}$ & $\begin{array}{c}\text { Sodium } \\
\text { sorbate } \\
\mathbf{X}_{2} \\
\end{array}$ & $\begin{array}{c}\text { Phosphoric } \\
\text { acid } \\
\mathbf{X}_{\mathbf{3}} \\
\end{array}$ & $\begin{array}{c}\log _{10} \mathrm{Cfu} \mathrm{ml}^{-1} \\
\text { TMB } \\
\mathrm{T}=4^{\circ} \mathrm{C} \\
\end{array}$ & $\begin{array}{c}\log _{10} \mathrm{Cfu} \mathrm{ml}^{-1} \\
\text { TMB } \\
\mathrm{T}=25^{\circ} \mathrm{C} \\
\end{array}$ \\
\hline 1 & 1248 & 0 & 1252 & 0.499 & 0.000 & 0.501 & 1.000 & 1.000 \\
\hline 2 & 1240 & 1260 & 0 & 0.496 & 0.504 & 0.000 & 3.301 & 3.602 \\
\hline 3 & 0 & 610 & 1890 & 0.000 & 0.244 & 0.756 & 3.623 & 3.716 \\
\hline 4 & 1240 & 1260 & 0 & 0.496 & 0.504 & 0.000 & 3.204 & 3.415 \\
\hline 5 & 0 & 2500 & 0 & 0.000 & 1.000 & 0.000 & 2.973 & 2.903 \\
\hline 6 & 618 & 1457 & 425 & 0.247 & 0.583 & 0.170 & 2.806 & 2.934 \\
\hline 7 & 0 & 0 & 2500 & 0.000 & 0.000 & 1.000 & 2.342 & 3.301 \\
\hline 8 & 0 & 1256 & 1244 & 0.000 & 0.503 & 0.497 & 2.079 & 2.380 \\
\hline 9 & 2500 & 0 & 0 & 1.000 & 0.000 & 0.000 & 2.716 & 2.982 \\
\hline 10 & 632 & 0 & 1868 & 0.253 & 0.000 & 0.747 & 1.623 & 1.845 \\
\hline 11 & 0 & 1934 & 566 & 0.000 & 0.774 & 0.226 & 2.914 & 2.914 \\
\hline 12 & 1248 & 0 & 1252 & 0.000 & 1.000 & 0.000 & 3.623 & 2.954 \\
\hline 13 & 1240 & 1260 & 0 & 1.000 & 0.000 & 0.000 & 2.833 & 2.732 \\
\hline 14 & 0 & 610 & 1890 & 0.000 & 0.000 & 1.000 & 2.176 & 2.602 \\
\hline 15 & 1240 & 1260 & 0 & 0.730 & 0.038 & 0.232 & 1.000 & 1.477 \\
\hline 16 & 0 & 2500 & 0 & 0.340 & 0.331 & 0.329 & 1.477 & 2.255 \\
\hline 17 & 618 & 1457 & 425 & 0.499 & 0.000 & 0.501 & 1.000 & 1.000 \\
\hline 18 & 0 & 0 & 2500 & 0.340 & 0.331 & 0.329 & 2.000 & 2.663 \\
\hline 19 & 0 & 1256 & 1244 & 0.000 & 0.503 & 0.497 & 2.892 & 2.903 \\
\hline 20 & 2500 & 0 & 0 & 0.496 & 0.504 & 0.000 & 2.663 & 2.663 \\
\hline
\end{tabular}

*Real scale - each component was re-scaled so that the total was 1.0 
The statistical analysis results of the data concerning the products stored at $4^{\circ} \mathrm{C}$ indicated that all ingredients of the preservative mixture had significant influence on the final number of cells. The statistical analysis results of the samples stored at $25^{\circ} \mathrm{C}$ were similar. Both regression models accounted for about $78 \%$ of variations (Tab. 2).

Table 2 Summary of ANOVA results for mixture design

\begin{tabular}{|c|c|c|c|c|c|c|c|}
\hline $\begin{array}{c}\text { Storage } \\
\text { temperature }\end{array}$ & Source & $\begin{array}{c}\text { Sum of } \\
\text { Squares }\end{array}$ & df & $\begin{array}{c}\text { Mean } \\
\text { Square }\end{array}$ & F value & p-value & $\operatorname{Adj}-\mathbf{R}^{2}$ \\
\hline \multirow{7}{*}{$4^{\circ} \mathrm{C}$} & Model & 10.54 & 3 & 3.51 & 19.26 & $<0.0001$ & \multirow{7}{*}{0.773} \\
\hline & Linear Mixture & 4.87 & 2 & 2.43 & 13.34 & 0.0004 & \\
\hline & $\mathbf{A C}$ & 5.67 & 1 & 5.67 & 31.11 & $<0.0001$ & \\
\hline & Residual & 2.92 & 16 & 0.18 & \multirow{4}{*}{2.12} & \multirow{4}{*}{0.1545} & \\
\hline & Lack of Fit & 1.98 & 8 & 0.25 & & & \\
\hline & Pure Error & 0.94 & 8 & 0.12 & & & \\
\hline & Cor Total & 13.46 & 19 & & & & \\
\hline \multirow{8}{*}{$25^{\circ} \mathrm{C}$} & Model & 9.30 & 4 & 2.33 & 18.25 & $<0.0001$ & \multirow{8}{*}{0.784} \\
\hline & Linear Mixture & 2.15 & 2 & 1.07 & 8.43 & 0.0035 & \\
\hline & $\mathbf{A B}$ & 0.44 & 1 & 0.44 & 3.42 & 0.0841 & \\
\hline & $\mathbf{A C}$ & 6.34 & 1 & 6.34 & 49.78 & $<0.0001$ & \\
\hline & Residual & 1.91 & 15 & 0.13 & & & \\
\hline & Lack of Fit & 0.92 & 7 & 0.13 & 1.06 & 0.4621 & \\
\hline & Pure Error & 0.99 & 8 & 0.12 & & & \\
\hline & Cor Total & 11.21 & 19 & & & & \\
\hline
\end{tabular}

Their usefulness for predicting the number of cells in the space established by the studied independent variables was finally confirmed by a lack-of-fit test. In both cases, the probability value $p$ was higher than 0.05 , which clearly suggests that the experimental models described the relationship between independent and dependent variables, expressed with the use of the equations presented in Tab. 3, with a satisfactory degree of quality.

Table 3 Final equations for the regression models describing the number of microbial cells in the product during storage at 4 and $25^{\circ} \mathrm{C}$.

\begin{tabular}{|c|c|c|c|}
\hline $\begin{array}{c}\text { Storage } \\
\text { temperature }\end{array}$ & $\begin{array}{l}\text { Componets } \\
\text { scale }\end{array}$ & Regression equation & Eq. \\
\hline \multirow[b]{2}{*}{$4^{\circ} \mathrm{C}$} & Real & $\begin{aligned} \log _{10} \text { Cfuml }^{-1}=2.706 \mathrm{X}_{1} & +3.197 \mathrm{X}_{2} \\
& +2.498 \mathrm{X}_{3} \\
& -6.961 \mathrm{X}_{1} \mathrm{X}_{3}\end{aligned}$ & (1) \\
\hline & Actual & $\begin{aligned} \log _{10} \text { Cfuml }^{-1}=1.08 & \times 10^{-3} \mathrm{X}_{1} \\
& +1.27 \times 10^{-3} \mathrm{X}_{2} \\
& +9.99 \times 10^{-4} \mathrm{X}_{3} \\
& -1.11 \times 10^{-6} \mathrm{X}_{1} \mathrm{X}_{3}\end{aligned}$ & (2) \\
\hline \multirow[b]{2}{*}{$25^{\circ} \mathrm{C}$} & Real & $\begin{aligned} \log _{10} \text { Cfuml }^{-1}=2.995 \mathrm{X}_{1} & +3.047 \mathrm{X}_{2} \\
& +3.068 \mathrm{X}_{3} \\
& -7.574 \mathrm{X}_{1} \mathrm{X}_{3}\end{aligned}$ & (3) \\
\hline & Actual & $\begin{aligned} \log _{10} \text { Cfuml }^{-1}=1.19 & \times 10^{-3} \mathrm{X}_{1} \\
& +1.21 \times 10^{-3} \mathrm{X}_{2} \\
& +1.22 \times 10^{-3} \mathrm{X}_{3} \\
& -1.21 \times 10^{-6} \mathrm{X}_{1} \mathrm{X}_{3}\end{aligned}$ & (4) \\
\hline
\end{tabular}

Apart from the main factors, the interaction between the concentration of sodium benzoate and phosphoric acid was also statistically significant (Tab. 2). This dependency was parabolic with a clearly marked minimum. The preservative mixture with a composition corresponding to this point was characterized by the highest effectiveness in inhibiting undesirable microflora growth during product storage (Figure 2a, b).
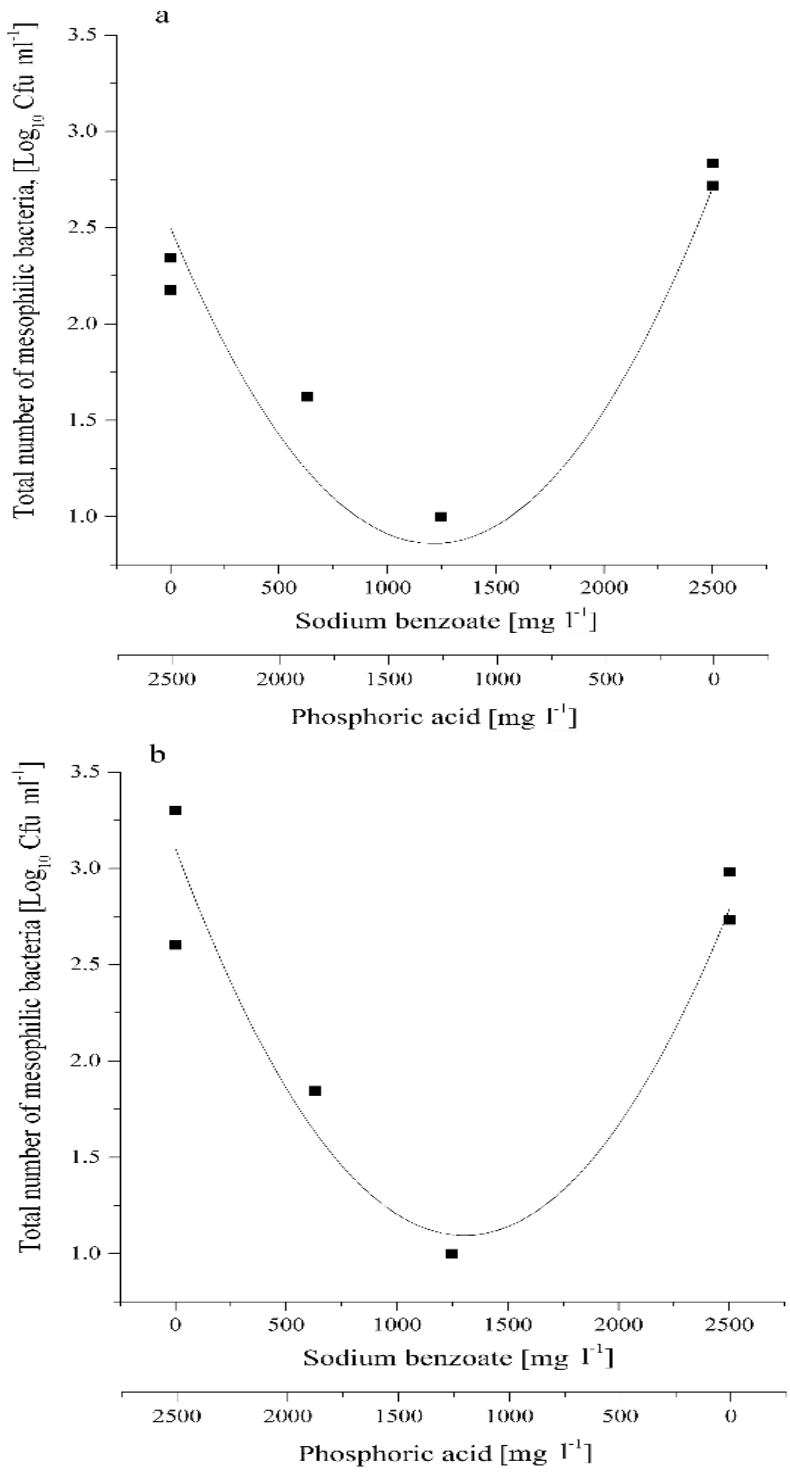

Figure 2 Interaction plot for sodium benzoate and phosphoric acid for products stored at 4 (a) and $25^{\circ} \mathrm{C}$ (b)

Increased concentration of sodium benzoate in the preservative mixture with a simultaneous decrease in the concentration of phosphoric acid had a negative influence on its effectiveness. This was caused by increased mixture $\mathrm{pH}$ resulting from a lower content of phosphoric acid (Figure 3 ). 


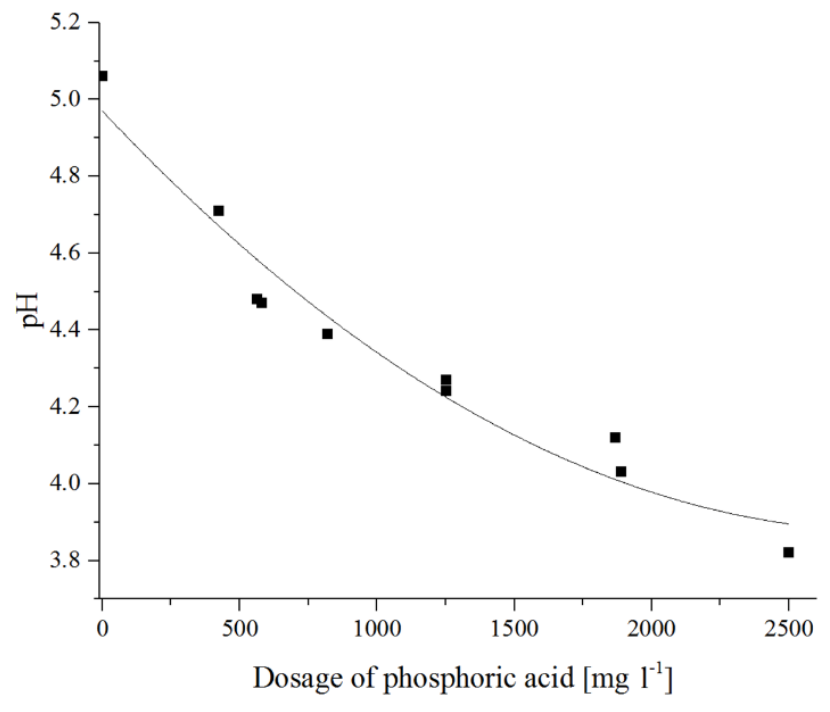

Figure 3 Influence of phosphoric acid concentration in the mixture on product $\mathrm{pH}$.

The antimicrobial activity of weak organic acids (benzoic and sorbic) and their salts (sodium benzoate and potassium sorbate) is highly dependent on the $\mathrm{pH}$ of the environment. In general, the lower the $\mathrm{pH}$, the higher the effectiveness of these substances (Alnoman et al., 2015). This mainly results from the fact that in solutions with highly acidic $\mathrm{pH}$, the majority of conjugated benzoic acid occur in their undissociated form. In accordance with the pKa value of benzoic acid, in order for the concentration of the undissociated form to equal $50 \%$, the $\mathrm{pH}$ of the solution should be 4.20. The low $\mathrm{pH}$ and clearly lipophilic nature of this molecule facilitates its penetration of the cell membrane, which contains a hydrophobic lipid layer. When inside a cell, benzoic acid are ionized, which results in the disturbance of substrate transportation process (including amino acids) and oxidative phosphorylation in the electron transport system. As a results of the ionization of acid molecules, protons are released inside the cell, which then becomes acidified. Consequently, not only the permeability of the cell membrane is altered, but also the intensity of some metabolic transformations (e.g. the Krebs cycle), which leads to the inhibition of cell growth (Chipley, 2005; Davidson et al., 2013). In the experiments performed with the use of preservative mixtures without phosphoric acid, the $\mathrm{pH}$ was 5.06. Therefore, the concentration of the undissociated form of benzoic acid, calculated using the Henderson-Hasselbalch equation, was about $12 \%$, which is in accordance with the literature (Baird-Parker, 1980). With such a low content of the undissociated form in the solution, the amount of preservative molecules penetrating into cells was most likely low, which explains the reduction of effectiveness in the case of preservative mixtures with no or low phosphoric acid content. The preservative mixture with a composition corresponding to the minimum on the parabola presented in Fig. 2a, b contained $1247.85 \mathrm{mg} \mathrm{l}^{-1}$ of sodium benzoate and $1252.15 \mathrm{mg}^{-1}$ of phosphoric acid. With this concentration of phosphoric acid, the $\mathrm{pH}$ of the product was 4.26 , which means, in accordance with the previously mentioned Henderson-Hasselbalch equation, that about $46 \%$ of benzoic acid molecules were in their undissociated form, which could easily penetrate bacterial cells envelope and cause growth inhibition.

\section{Process optimization and validation}

In order to establish the optimum composition of the preservative mixture, optimization calculations were conducted using the simplex method, which provides excellent results in the search for the local minimums of functions of several variables (Nelder and Mead, 1965). According to these calculations, the product should contain only benzoic and phosphoric acids in its composition (Figure $4 a, b$ ). There is also no need to use the third of the studied preservatives, potassium sorbate, which is very beneficial from the point of view of the costs associated with the production of the Yarrowia lipolytica yeast biomass-based supplement. The predicted number of cells, expressed as $\log _{10} \mathrm{Cfu} \mathrm{ml}^{-1}$, after 30 days should be equal to $0.914 \pm 0.23$ and $1.095 \pm 0.19$, respectively, for samples stored at temperatures of 4 and $25^{\circ} \mathrm{C}$.

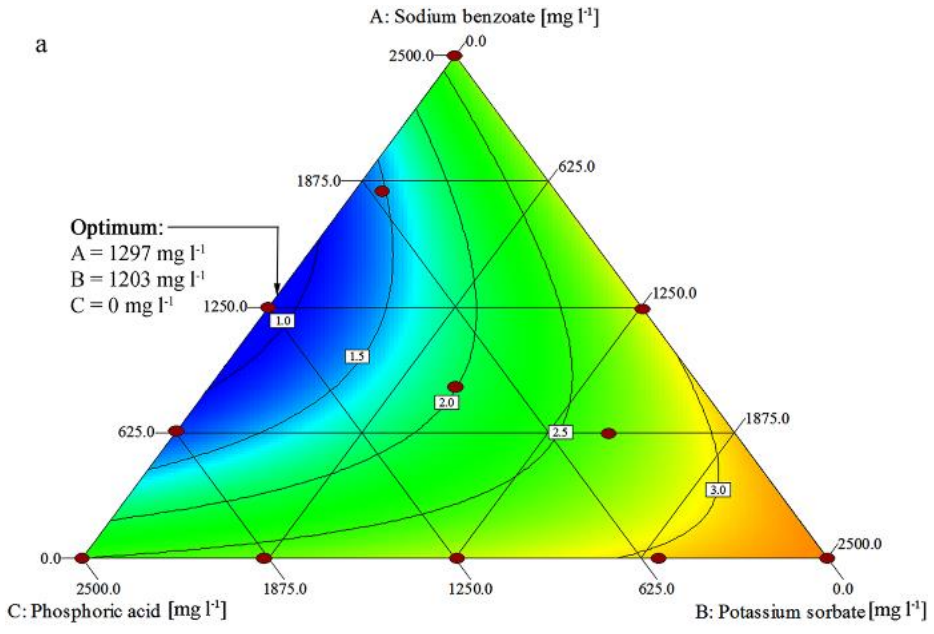

Total aerobic mesophilic bacteria $\left[\log _{10} \mathrm{Cfu} \mathrm{ml}^{-1}\right], \bullet$ - Design points, $1.00 \square 3.62$

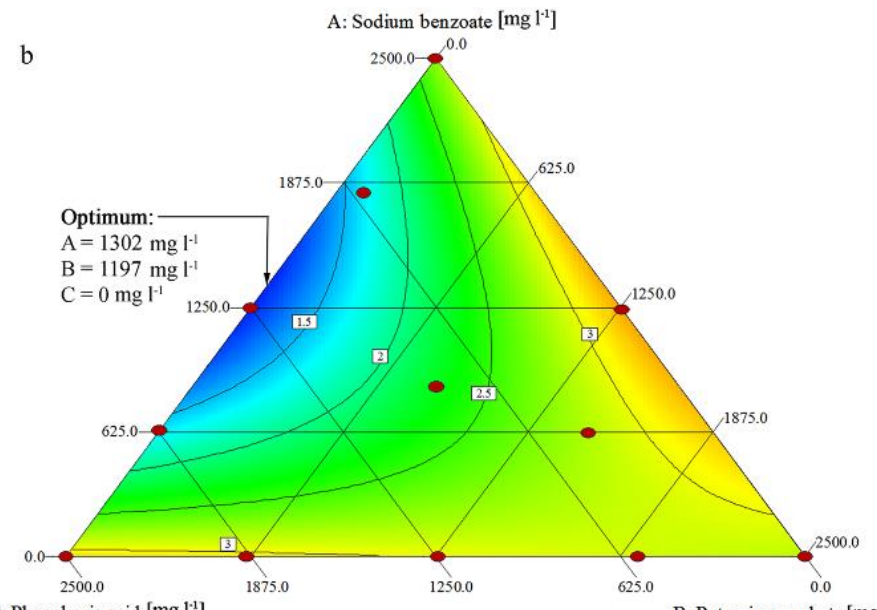

C: Phosphoric acid [mg l ${ }^{1-1}$

B: Potassium sorbate $\left[\mathrm{mg}^{-1}\right]$

Total aerobic mesophilic bacteria $\left[\log _{10} \mathrm{Cfu} \mathrm{ml}^{-1}\right], \bullet$ - Design points, $1.00 \square 3.72$

Figure 4 Contour plot depicting the relation between sodium benzoate, potassium sorbate, and phosphoric acid and the total number of mesophilic bacteria in the product during storage at 4 (a) and $25^{\circ} \mathrm{C} \mathrm{(b)}$

In order to verify the acquired data, a validation study was performed in accordance with the new technological premises resulting from optimization and the analysis of the control points on the production line. In accordance with the new guidelines, a concentrate of preservative substances was added to cell homogenate in the process of hydrodynamic cavitation during the 16 passage of the cell suspension through a cavitation head. The product was stored at 4 and $25^{\circ} \mathrm{C}$ for a period of 60 days.

The applied production process modifications enabled the uniformity of the cel homogenate and the reduction of the levels of infection with foreign microflora during distribution to packages. The product maintained its stability throughout a period twice as long as the one originally assumed (Figure 5). The number of bacterial cells was within the prediction interval established during optimization calculations, which explicitly confirms their correctness. 


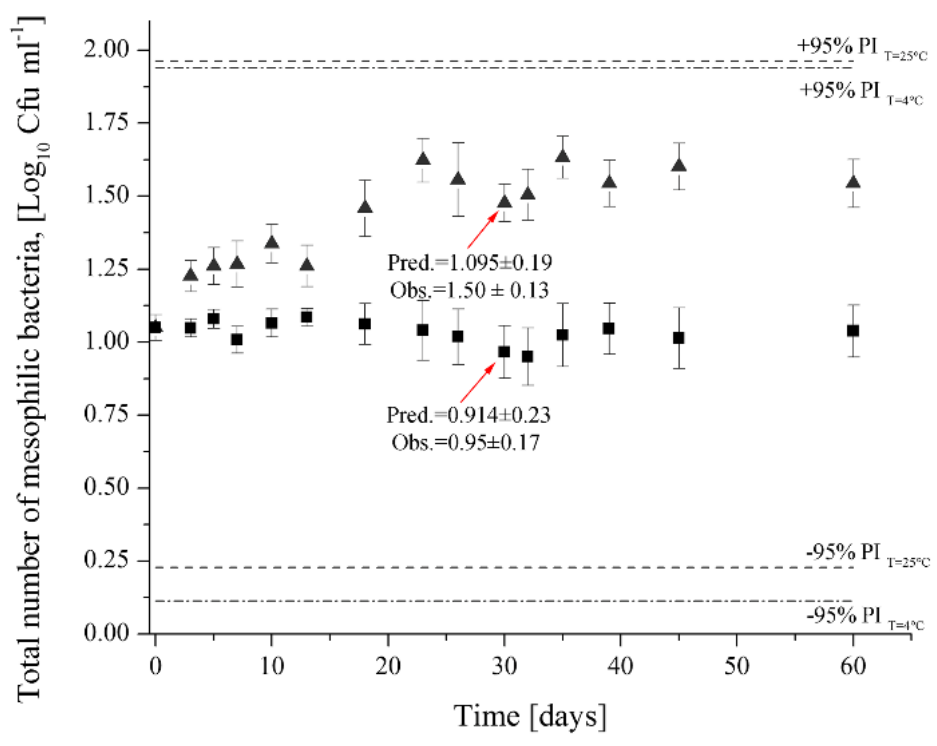

Figure 5 Changes in the total number of mesophilic bacteria during 60 days of storage at temperatures of $4(\boldsymbol{\square})$ and $25^{\circ} \mathrm{C}(\boldsymbol{\Delta})$. -..-.-. - prediction interval for samples stored at $4^{\circ} \mathrm{C}$, ----- - prediction interval for samples stored at $25^{\circ} \mathrm{C}$

\section{DISCUSSION}

Sodium benzoate, potassium sorbate, and phosphoric acid were selected for research focusing on the improvement of microbiological stability of innovative dietary supplement for farm animals. These substances were chosen mainly because of the fact that their use in food and animal feeds is authorized and that they possess the GRAS (Generally Recognized As Safe) status (Busta et al. 2005; Chipley, 2005). Other factors that were taken into consideration included the ease of their introduction into the product, lack of taste, smell, or color, as well as the relatively low cost of purchase. It was also taken into account that these compounds, especially benzoic acid, naturally occur in many fruit (grapes, blackcurrants, apples, cherries, strawberries), fermented products (black tea, smear-ripened cheese, wine, beer), and other products, such as honey or mushrooms. Benzoic acid is also produced by the Lactobacillus plantarum probiotic bacteria (Niku-Paavola et al., 1999). When it comes to sorbic acid, it naturally occurs in rowanberries (Busta et al., 2005). The concentration of these substances in products of natural origin is very diverse, e.g. the content of benzoic acid ranges from 10 to $1000 \mathrm{mg} \mathrm{kg}^{-1}$ (Chipley, 2005). In the presented work, the optimum concentration of sodium benzoate in cell homogenate of the yeast Yarrowia lipolytica (constituting a diet supplement for farm animals) stored at $4^{\circ} \mathrm{C}$ was $1297 \mathrm{mg} \mathrm{l}^{-1}$, while for products stored at $25^{\circ} \mathrm{C}$ it equaled $1307 \mathrm{mg} \mathrm{l}^{-1}$. A very similar combination, in terms of the concentration of benzoic acid and $\mathrm{pH}$ (1250 $\mathrm{mg} \mathrm{l}^{-1}$ and $\mathrm{pH} 3.9$ ), was used for the stabilization of pasteurized papaya juice (Okoli and Ezenweke, 1990). The bottled drink was stored for 80 weeks at temperatures of 10 and $30{ }^{\circ} \mathrm{C}$, while the control sample, which underwent the process of pasteurization only, remained fresh for just 20 weeks. The use of sodium benzoate at a concentration of $1000 \mathrm{mg} \mathrm{l}^{-1}$ also significantly extended the shelf life of a tamarind drink. Significant deterioration of the control sample was visible as early as after two days of storage at room temperature; the addition of sodium benzoate extended shelf life by forty days (Adeola and Aworh, 2014). According to the data found in the literature, the minimum inhibitory concentration (MIC) of benzoic acid for bacteria ranges from 50 to $3000 \mathrm{mg} \mathrm{l}^{-1}$ (Chipley, 2005). The resistance of yeasts and fungi to benzoic acid is also very diverse. In the case of Sporogenic yeast, MIC ranges from 20 to 200 (pH 2.6 4.5), while successful inhibition of the growth of Zygosaccharomysec bail requires the use of concentrations between 1200 and $4500 \mathrm{mg}^{-1}(\mathrm{pH} \mathrm{4.0-4.8)}$ (Praphailong and Fleet, 1997). Among fungi, the highest resistance to benzoic acid is exhibited by the Aspergillus parasiticus (>4000 $\mathrm{mg} \mathrm{l}^{-1}, \mathrm{pH} 5.5$ ) and

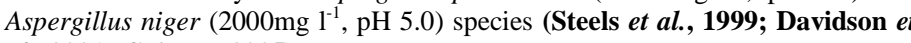
al., 2001; Chipley, 2005). Our results concerning lower antimicrobial activity of potassium sorbate, when compared to the activity of sodium benzoate, could be probably attributed to the fact, that certain bacterial strains are not inhibited by sorbate, and some may even metabolize the compound (Sofos, 1989). Overall, potassium sorbate is considered as a more effective inhibitor of yeasts and molds than bacteria (Sofos, 1989; Marie Skirdal and Eklund, 1993; Busta et al. 2005). In general, the effectiveness of such preservatives as weak organic acids is dependent on the type of strain and environmental conditions $(\mathrm{pH}$, ionic strength, surfactant presence). A single strain may exhibit different resistance to a given preservative depending on the environmental conditions in which it occurs (Busta et al., 2005). Therefore, a series of optimization studies needs to be conducted each time to establish the actual doses of preservative substances required to effectively inhibit the growth of undesirable microflora
In accordance with the applicable legislation, the studied preservatives are authorized for use as feed additives (70/524/EEC; EC 1831/2003; Comission, 2004). Moreover, in May 2011, the European Commission passed a regulation concerning the authorization of sodium benzoate as a feed additive for weaned piglets. This product is intended for use in weaned piglets from weaning to 120 days of age (or $35 \mathrm{~kg} \mathrm{bw}$ ) at a dose of $4000 \mathrm{mg} \mathrm{kg}-1$ of complete feeding stuffs In accordance with the opinion prepared by experts from the Panel on Additives and Products or Substances used in Animal Feed (FEEDAP) of the European Food Safety Authority (EFSA), sodium benzoate is safe for target species at the proposed dose with a margin of safety of approximately three (EFSA Panel, 2011). The research on which the above-mentioned directive was based indicates that benzoate is rapidly excreted and no residues or accumulation occur. Moreover, the initiator (Kemira, Sweden) provided five efficacy trials, two of which showed a significant benefit in terms of final body weight. In addition, a meta-analysis made by pooling data from the five trials showed a significant improvement of the feed to gain ratio. Consequently, the FEEDAP concludes that sodium benzoate at a dose of $4000 \mathrm{mg} \mathrm{kg}-1$ of complete feed has the potential to improve performance in weaned piglets. In 2012, the FEEDAP prepared an expertise on the safety and efficacy of sodium benzoate as a silage additive for pigs, poultry, bovines, ovines, goats, rabbits and horses. Three studies with laboratory-scale silos are described, each lasting at least 90 days (EFSA Panel, 2012). The results showed that the application of sodium benzoate in the preparation of silage up to the maximum proposed dose of $2400 \mathrm{mg} \mathrm{kg}^{-1}$ of forage was safe for the target animals. It was demonstrated that sodium benzoate at concentrations between 250 and $2500 \mathrm{mg} \mathrm{kg}^{-1}$ forage also has the potential to increase the aerobic stability of ensiled materials at a wide range of dry matter contents.

\section{CONCLUSIONS}

Our experiments showed significant improvement in the microbial quality of diet supplement, when compared to the control sample without preservatives addition. In this study, the established optimum doses of chemical preservatives were lower than the doses included in the above-mentioned documents of the European Commission. It can be concluded that the novel diet supplement based on the homogenate of the cells of yeast Yarrowia lipolytica can be considered safe for animals.

Acknowledgments: The research was performed with the use of funding from a Project entitled "The use of cavitation methods in the production of a unique feed protein” implemented as part of the „INNOTECH” Program (path: HI-TECH) of The National Center for Research and Development (INNOTECHK1/HI1/7/159645/NCBR/12).

The authors would also like to thank Mr Franciszek Baszczok, development director of Skotan S.A., for his factual input into the preparation of this publication, associated especially with the innovative process of hydrodynamic cavitation used for the disintegration of Yarrowia lipolytica yeast cells.

\section{REFERENCES}

70/524/EEC, Council directive of 23 November 1970 concerning additives in feeding-stuffs. Official Journal of the European Communities L 270/1, 840-856.

ADEOLA, A.A., AWORH, O.C., 2014. Effects of sodium benzoate on storage stability of previously improved beverage from tamarind (Tamarindus indica L.). Food Science \& Nutrition 2, 17-27. http://dx.doi.org/10.1002/fsn3.78

ADERINOLA, T.A., OLUWAMUKOMI, M.O., 2014. Effect of sodium benzoate on the quality and sensory properties of kunun-zaki supplemented with groundnut. Journal of Microbiology, Biotechnology and Food Sciences 3(5), 426 431

ALNOMAN, M., UDOMPIJITKUL, P., PAREDES-SABJA, D., SARKER, M.R., 2015. The inhibitory effects of sorbate and benzoate against Clostridium perfringens type A isolates. Food Microbiology 48, 89-98 http://dx.doi.org/10.1016/j.fm.2014.12.007

BAIRD-PARKER, A.C., 1980. Organic Acids, In: SILLIKER, J.H. (Ed.), Microbial Ecology of Foods, Academic Press, New York, pp. 126-135. ISBN: 978-0-12-363521-1. http://dx.doi.org/10.1016/B978-0-12-363521-1.50014-0

BASZCZOK, F., RYMOWICZ, W., 2011. Microbiologica reprocessing of byproducts from biodiesel production. Patent number US 2011/0111090.

BERTHEAU, Y., DAVISON, J., 2011. Soybean in the European Union, status and perspective, In: KREZHOVA, D. (Ed.), Recent trends for enhancing the diversity and quality of soybean products, InTech Europe, Croatia, pp. 3-46 ISBN: 978-953-307-533-4. http://dx.doi.org/10.5772/18896

BUSTA, F.F., STOPFORTH, J.D., SOFOS, J.N., 2005. Sorbic Acid and Sorbates, Antimicrobials in Food, Third Edition, CRC Press, pp. 49-90. ISBN: 978-0-8247-4037-5. http://dx.doi.org/10.1201/9781420028737.ch3

CAMPOS, A.F., PEREIRA, O.G., RIBEIRO, K.G., SANTOS, S.A., VALADARES FILHO, S.D.C., 2014. Impact of replacing soybean meal in beef cattle diets with inactive dry yeast, a sugarcane by-product of ethanol distilleries and sugar mills. Animal Feed Science and Technology 190, 38-46. http://dx.doi.org/10.1016/j.anifeedsci.2014.01.003 
CHIPLEY, J.R., 2005. Sodium Benzoate and Benzoic Acid, Antimicrobials in Food, Third Edition, CRC Press, pp. 11-48. ISBN: 978-0-8247-4037-5. http://dx.doi.org/10.1201/9781420028737.ch2

COMISSION, 2004. List of the authorised additives in feedingstuffs published in application of Article 9t (b) of Council Directive 70/524/EEC concerning additives in feedingstuffs. Official Journal C 50, 1-144.

COX, D.R., REID, N., 2000. Factorial designs, The Theory of the Design of Experiments, Chapman and Hall/CRC. ISBN: 978-1-58488-195-7. http://dx.doi.org/10.1201/9781420035834.ch6

COZANNET, P., PRIMOT, Y., GADY, C., MÉTAYER, J.P., CALLU, P. LESSIRE, M., SKIBA, F., NOBLET, J., 2010. Ileal digestibility of amino acids in wheat distillers dried grains with solubles for pigs. Animal Feed Science and Technology 158, 177-186. http://dx.doi.org/10.1016/j.anifeedsci.2010.04.009

DAVIDSON, M.P., JUNEJA, V.K., BRANEN, J.K., 2001. Antimicrobial Agents, In: III, J.H.T., SALMINEN, S., BRANEN, L.A., DAVIDSON, M.P. (Eds.), Food Additives, CRC Press, Boca Raton FL. ISBN: 978-0-8247-9343-2. http://dx.doi.org/10.1201/9780824741709.ch20

DAVIDSON, P.M., TAYLOR, T.M., SCHMIDT, S.E., 2013. Chemical Preservatives and Natural Antimicrobial Compounds, In: DOYLE, M.P., BUCHANAN, R.L. (Eds.), Food Microbiology: Fundamentals and Frontiers, American Society of Microbiology, Washington http://dx.doi.org/10.1128/9781555818463.ch30

EC 1831/2003, European Union Register of Feed Additives. Edition 205. Appendixes 3e, 4 - 19.02.2015.

EFSA PANEL, 2011. EFSA Panel on Additives and Products or Substances used in Animal Feed (FEEDAP); Scientific Opinion on Safety and efficacy of Protural (sodium benzoate) as feed additive for weaned piglets. EFSA Journal 9(2):2005. http://dx.doi.org/10.2903/j.efsa.2011.2005

EFSA PANEL, 2012. EFSA Panel on Additives and Products or Substances used in Animal Feed (FEEDAP); Scientific opinion on the safety and efficacy of sodium benzoate as a silage additive for pigs, poultry, bovines, ovines, goats, rabbits and horses. EFSA Journal 10(7):2779.

KWIATEK, K., KUKIER, E., WASYL, D., HOSZOWSKI, A., 2008. Microbiological quality of compound feedstuffs in Poland. Medycyna Weterynaryjna 64, 949-954.

LENNERZ, B.S., VAFAI, S.B., DELANEY, N.F., CLISH, C.B., DEIK, A.A., PIERCE, K.A., LUDWIG, D.S., MOOTHA, V.K., 2015. Effects of sodium benzoate, a widely used food preservative, on glucose homeostasis and metabolic profiles in humans. Molecular Genetics and Metabolism 114, 73-79. http://dx.doi.org/10.1016/i.ymgme.2014.11.010

MARIE SKIRDAL, I., EKLUND, T., 1993. Microculture model studies on the effect of sorbic acid on Penicillium chrysogenum, Cladosporium cladosporioides and Ulocladium atrum at different $\mathrm{pH}$ levels. Journal of Applied Bacteriology 74, 191-195. http://dx.doi.org/10.1111/j.1365-2672.1993.tb03014.x

NELDER, J.A., MEAD, R., 1965. A Simplex Method for Function Minimization. The Computer Journal 7, 308-313. http://dx.doi.org/10.1093/comjnl/7.4.308

NIKU-PAAVOLA, M.L., LAITILA, A., MATTILA-SANDHOLM, T., HAIKARA, A., 1999. New types of antimicrobial compounds produced by Lactobacillus plantarum. Journal of Applied Microbiology 86, 29-35. http://dx.doi.org/10.1046/j.1365-2672.1999.00632.x

OKOLI, E.C., EZENWEKE, L.O., 1990. Formulation and shelf-life of a bottled pawpaw juice beverage. International Journal of Food Science \& Technology 25 , 706-710. http://dx.doi.org/10.1111/j.1365-2621.1990.tb01132.x

PLUMED-FERRER, C., VON WRIGHT, A., 2009. Fermented pig liquid feed nutritional, safety and regulatory aspects. Journal of Applied Microbiology 106, 351-368. http://dx.doi.org/10.1111/j.1365-2672.2008.03938.x

PN-EN ISO 4833-2:2013-12, Microbiology of the food chain -- Horizontal method for the enumeration of microorganisms -- Part 2: Colony count at 30 degrees $\mathrm{C}$ by the surface plating technique. Polish Committee for Standardization, Poland,

PN-EN ISO 6579:2003, Microbiology of food and animal feeding stuffs -Horizontal method for the detection of Salmonella spp. Polish Committee for Standardization, Poland,

PN-EN ISO 6887-1:2000, Microbiology of food and animal feeding stuffs -Preparation of test samples, initial suspension and decimal dilutions for microbiological examination -- Part 1: General rules for the preparation of the initial suspension and decimal dilutions. Polish Committee for Standardization, Poland,

PN-EN ISO 7218:2008, Microbiology of food and animal feeding stuffs -General requirements and guidance for microbiological examinations. Polish Committee for Standarization, Poland,

PN-ISO 4831:1998, Microbiology of food and animal feeding stuffs --General guidance for the enumeration of coli forms - Most probable number technique. Polish Committee for Standardization, Poland,

PN-ISO 21527-1:2009, Microbiology of food and animal feeding stuffs -Horizontal method for the enumeration of yeasts and moulds -- Part 1: Colony count technique in products with water activity greater than 0,95 . Polish Committee for Standardization, Poland,
PRAPHAILONG, W., FLEET, G.H., 1997. The effect of pH, sodium chloride, sucrose, sorbate and benzoate on the growth of food spoilage yeasts. Food Microbiology 14, 459-468. http://dx.doi.org/10.1006/fmic.1997.0106

RYMOWICZ, W., 2009. A new strain of yarrowia lipolytica and its use in the industrial reclamation of glycerol fractions obtained during biodiesel production. Patent number WO/2009/061225.

RYWIŃSKA, A., JUSZCZYK, P., WOJTATOWICZ, M., ROBAK, M., LAZAR, Z., TOMASZEWSKA, L., RYMOWICZ, W., 2013. Glycerol as a promising substrate for Yarrowia lipolytica biotechnological applications. $\begin{array}{llll}\text { Biomass and } \quad \text { Bioenergy } & 48, & 148-166 .\end{array}$ http://dx.doi.org/10.1016/j.biombioe.2012.11.021

SOFOS, J.N., 1989. Sorbate Food Preservatives. CRC Press, Boca Raton FL, ISBN: 9780849367861

STEELS, H., JAMES, S.A., ROBERTS, I.N., STRATFORD, M., 1999. Zygosaccharomyces lentus: a significant new osmophilic, preservative-resistant spoilage yeast, capable of growth at low temperature. Journal of Applied Microbiology 87, 520-527. http://dx.doi.org/10.1046/j.1365-2672.1999.00844.x

TILMAN, D., CASSMAN, K.G., MATSON, P.A., NAYLOR, R., POLASKY, S., 2002. Agricultural sustainability and intensive production practices. Nature 418, 671-677. http://dx.doi.org/10.1038/nature01014 